\title{
THE STATUS OF COMMONS IN THE CHANGING LANDSCAPE IN THE CZECH REPUBLIC
}

\author{
ALŽBĚTA VOSMÍKOVÁ ${ }^{1,2}$ and ZDENKA K ǨENOVÁ $1,2, *$ \\ ${ }^{1}$ Global Change Research Centre AS CR, v.v.i., Bělidla 4a, CZ-60200 Brno, Czech Republic \\ 2 Institute for Environmental Studies, Faculty of Science, Charles University, Benátská 2, CZ-12900 Prague, Czech Republic. \\ * Corresponding author: krenova.z@czechglobe.cz
}

\section{ABSTRACT}

Commons were ancient pastures, which once occurred in every village in many countries, including the Czech Republic. They have been a landscape and social phenomenon for decades. However, social and economic changes brought an end to community ownership and traditional management of these commons. The number of commons has been decreasing since the middle of the 19th century and currently very few remain. This paper evaluates the status of former commons in 35 cadastres in south-western Bohemia and describes the changes they have undergone in the last two hundred years. Three historical periods were identified as the main drivers in the changes in the status of commons. We started with a period from the middle of the 19th century to the 1950s, the second from 1950s to 1990s and the last from 1990s to 2019. Aerial images and field surveys revealed that $93 \%$ of former commons disappeared due to afforestation, conversion to fields and natural succession occurring on abandoned commons. The social and economic aspects associated with these changes are mentioned. Some of the commons are part of the Territorial system of landscape ecological stability (Ecological networks) and we suggest that more of the remaining commons should be included in this network. They could play a role in maintaining biodiversity and providing stepping stones in a uniform agriculture landscape. We propose to evaluate the conservation and ecosystem value of these commons in more detail and set up the appropriate management essential for the preservation or restoration of commons, an indisputable part of our biological and cultural heritage.

Keywords: aerial images; commons; historical maps; land use changes

\section{Introduction}

"The tragedy of Commons" by Hardin (1968) inspired this study, however we see the tragedy of commons from a different point of view. We tried to determine whether the current state of the commons can be described only as a tragedy or whether there is hope that commons provide opportunities for improving uniform landscapes. This study evaluates the status of commons over nearly two hundred years.

The Central European region has been significantly affected by human activities for centuries. Wildness was gradually transformed into a cultural landscape permanently managed by humans. The richness and diversity of rural landscapes is a European phenomenon and a consequence of the long history of the Old Continent landscape. However, recently the rural landscape in Central Europe changed significantly. The scale of change has increased and accelerated during the last decades. Transformation of agriculture, new technologies and socio-economic changes are the main drivers of these changes in land use (Mander et al. 2004). Grazing land is one of the most affected habitats (Palang et al. 2006). Grazing animals, recognised as important drivers of Central European landscape structure and regional diversity, have almost completely disappeared in recent decades.

Since the Middle Ages, common pastures, often called commons, used to be a common feature of the Central European landscape. They are a traditional phenomenon in many aspects, including biological and cultural. Commons were nutrient poor, waterlogged or stony localities, not suitable for agriculture, and were usually used daily for mixed grazing. The daily regime was controlled by a municipal shepherd, who brought the herd to the common and back to the stables every day. Long term low-intensity mix grazing resulted in commons being localities rich in different habitats and species, and home to many protected species. Thanks to small fertilizer input and extensive grassland use, common pastures are semi-natural grasslands with a high conservation value, which are often called "biodiversity hotspots" or "biodiversity refugia" (e.g. Rook and Tallowin 2003 or Hodgson et al. 2011). The importance of commons for the Central European fauna and flora has already been confirmed by several studies. For example, the importance of commons as bird refugia is confirmed by Schwarz et al. (2018). Berg et al. (2011) emphasize the importance of commons for the conservation of large butterfly populations. Their high biological value is enhanced by their high conservation value in this area. Many small protected areas (i.e. nature reserves, nature monuments) were established in previous commons.

This study evaluates the status of former commons in south-western Bohemia. The area of interest includes the wider surroundings of the village Těchonice, where many commons were preserved or restored thanks to the enthusiasm and care of local residents. The commons called "Těchonické draha" are the Arch of biodiversity hosting many specific habitats and species. To better understand the status of commons and how they have changed over time, we analysed the status of commons in four periods: the 1850s, 1950s, late 1990s and 2019 and discuss the 


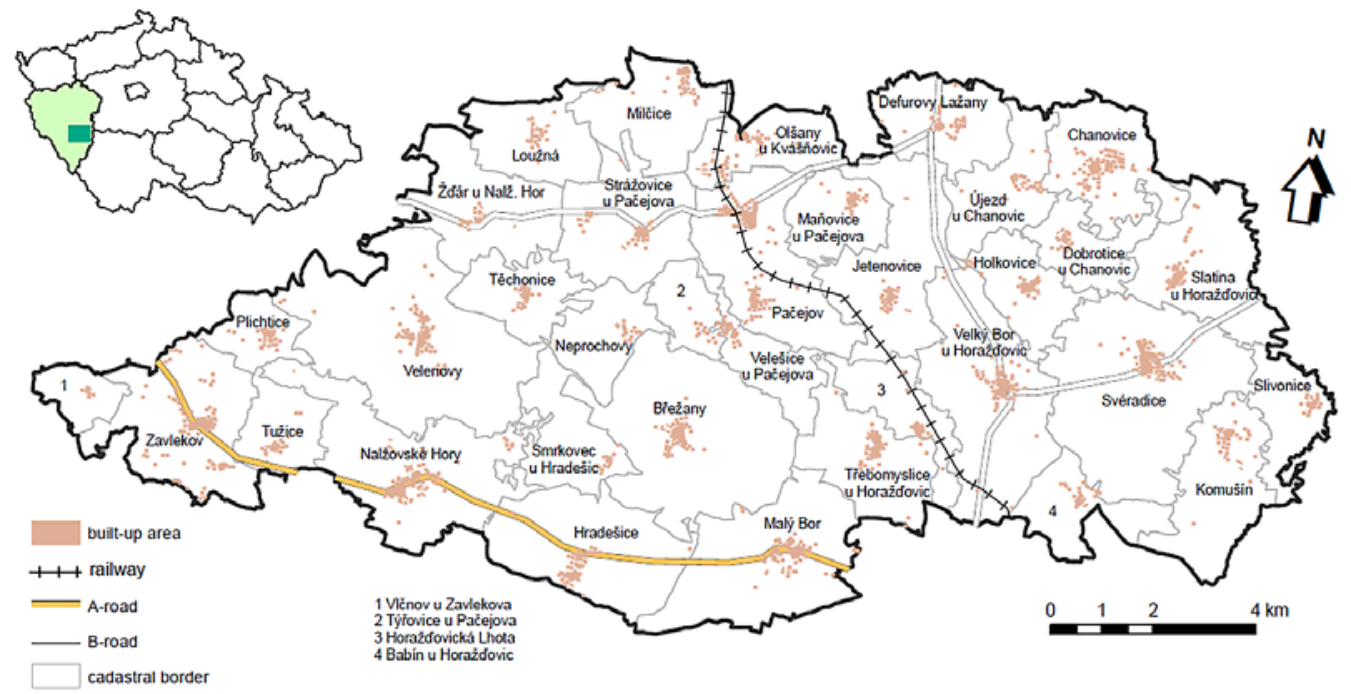

Fig. 1 Area studied.

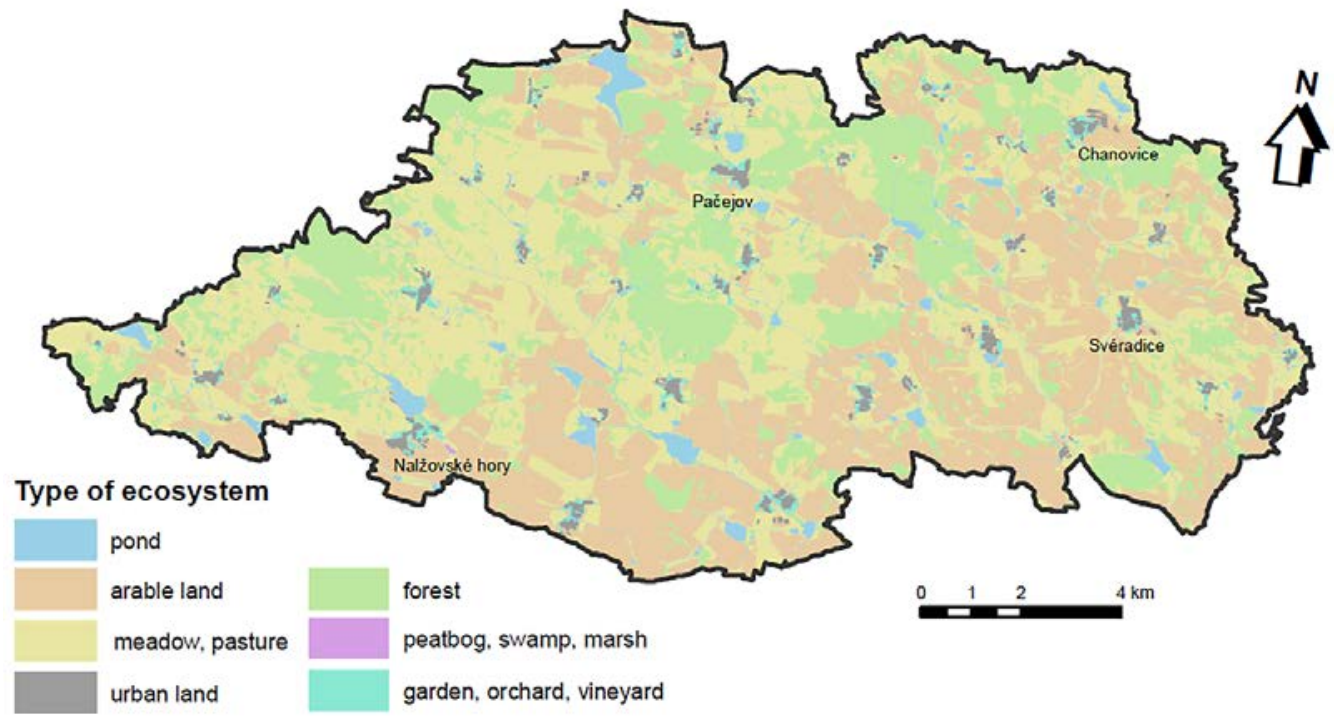

Fig. 2 Map showing the distribution of particular habitats in the area studied.

changes that occurred in each period. Finally, we discuss the potential of commons for improving the quality of the current landscape and mitigation of effects of climate change.

\section{Methods}

\section{Study area}

The area studied is located in the Pilsen region, in the south-western part of the Czech Republic (Fig. 1). It has an area of $17 \mathrm{~km}^{2}$ and consists of 35 cadastral areas. The largest settlements are Nalžovské Hory with over 1000 inhabitants and Chanovice and Pačejov with over 700 permanent inhabitants. The area is characterized by a rural landscape with ponds, many pastures, small villages and low density of transport infrastructure. The only trans- port infrastructure through the area is the railway corridor Pilsen - České Budějovice. The area selected is quite similar to other parts of the Czech Republic (e.g. some regions at low altitudes in the Šumava Protected Landscape Area or the Vysočina region (Culek et al. 2013)).

Climatic conditions in most of the area studied is mildly warm and warm in the southern part (Cenia 2017). Most of the area is composed of intrusions of Central Bohemian pluton, especially granodiorites, or granits, which often rise up in the terrain in the form of large boulders or rocks. The soil cover consists mainly of acidic cambisols. Forests, mostly of spruce or pine, cover about $20 \%$ of the area (Culek et al. 2013). In general, fields are present in a non-forest landscape, in which pastures and meadows are less abundant. However, meadows and pastures predominate in the north-western part of this area (Fig. 2). 


\section{Processing of data}

This study involved: 1) the vectorization of data, 2) comparison of aerial images with other maps, 3) field research in autumn 2019 and spring 2020.

Because the data needed is not yet available for the area studied, we first created a vector layer of former municipal pastures. Imprints of historical maps of Stable Cadastre for half of the 19th century (Semotánová 1998) provided by ČÚZK (2020) were used. Four categories of commons based on their size were distinguished: (i) micro - with a size of $0.5 \mathrm{ha}$, (ii) small $-0.5-1.5 \mathrm{ha}$, (iii) medium $-1.5-5$ ha and (iv) macro- more than 5 ha. In order to analyse their status, the layer of segments of commons was compared with aerial images from 1951, 1999 and 2019. Aerial photographs from 1951 indicate the traditional structure of the landscape before collectivization and the creation of agricultural cooperatives, by which the communists fundamentally changed the economy in the countryside. Aerial photographs from 1999 are of the landscape at the end of the first decade of post-communism, when agricultural land was returned to the former owners, sold or privatised. Finally, the current situation is recorded in the aerial photographs from 2019.

The following commons were categorized in each period:

1) preserved commons - more than $2 / 3$ of which are covered with a mosaic of grassland vegetation;

2) abandoned - more than $2 / 3$ of which are covered with naturally regenerated trees or shrubs as they are no longer used for grazing animals;

3) afforested - more than $2 / 3$ of which were afforested;

4) converted to fields - more than $2 / 3$ of which were improved by melioration, drainage or other technical adjustments and transformed into arable land;

5) built up - more than $2 / 3$ of which was covered with houses or other infrastructures (e.g. agriculture buildings, playgrounds, municipal waste landfills etc.);

6) other - more than $2 / 3$ of which was converted to something other than that listed above.

The database included all the above data and used in the following research.

Then, the commons in current aerial photographs categorised as preserved and larger than 0.5 ha (i.e. size category (ii) small, (iii) medium and (iv) large), were selected. A layer consisting of these commons was overlaid with the following maps:

- consolidated layer of ecosystems,

- Natura 2000 habitats,

- protected species listed in the Nature Conservation Finding Database.

Finally, the status of preselected commons was verified in the field. Field surveys were carried out in autumn 2019 and spring 2020 to determine whether the characteristics based on the aerial photographs (i.e. the size of the open area and the assumed mosaic nature of the habitat) correspond with that observed in the field. The field survey confirmed or refuted the inclusion of a common on the list of preserved commons. This verification also helped us to determine whether the aerial photographs could also be used to identify preserved commons.

\section{Results}

\section{Commons in the middle of the 19th century}

The typical rural landscape in the middle of the 19th century consisted mainly of small private fields, sporadically distributed in extensive forests, along with commons and generally little urbanisation. For centuries, the acreage of arable land increased at the expense of forests. The middle of the 19th century is when the area of forest in our landscape reached the historically lowest value and there were no further possibilities for increasing the area of agricultural land and the agricultural landscape was formed (Bičík 2010 in Vachuda 2017).

In the middle of the 19th century, large commons occurred further from the centres of villages than the small commons that occurred irregularly along paths, between fields, around houses and in gardens. In many areas, all these typical formations were evenly represented in the rural landscape.

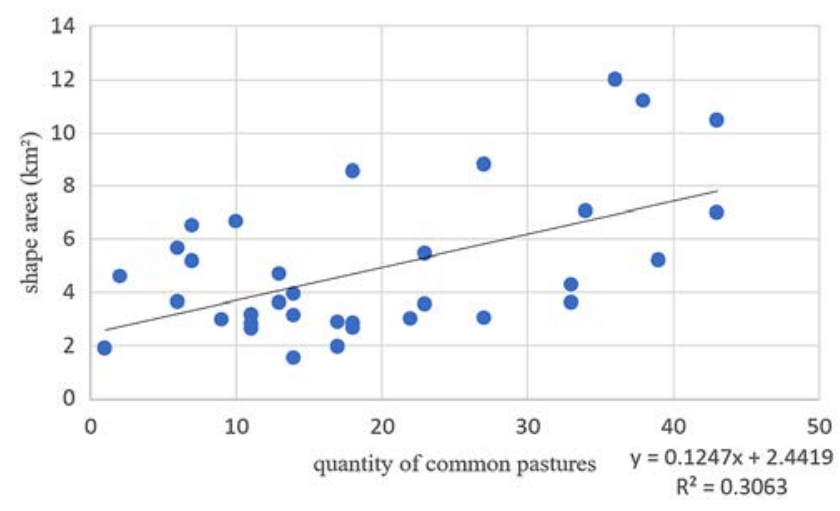

Fig. 3 The relationship between the number of commons and the size of the cadastral area.

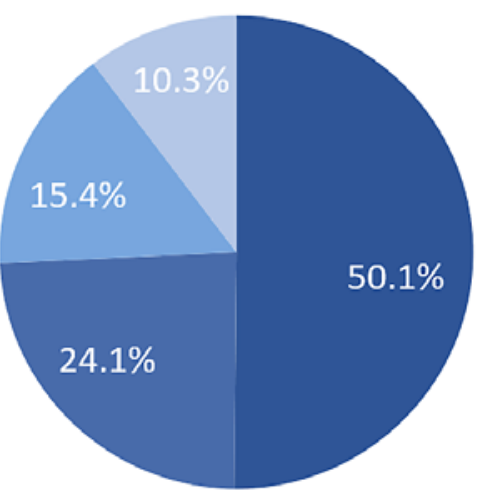

a micro $\square$ small $\square$ medium $\square$ large

Fig. 4 Pie diagram illustrating the percentage of commons in each of the size categorises. 
Based on historical maps from the middle of the 19th century, 668 commons were in the area studied. As expected, the number increased with the size of the cadastral area, but the relationship is not very strong (Fig. 3).

The size of commons varies markedly and they are not distributed uniformly in terms of size categories (Fig. 4). More than $50 \%$ of all commons are smaller than 0.5 ha. These small and often narrow commons were usually used as corridors for moving grazing animals from one pasture to another. Herds of cattle used them for a short stop during their regular trips to large pastures and therefore they occur more frequently than large commons.

\section{The early 1950s}

The aerial photographs from the early 1950s reflect the situation in Czechoslovakia after World War II and at the beginning of the socialist era. Land reforms started after the Communist revolution in 1948. However, aerial photographs from the early 1950s reveal that the area studied has not changed significantly in that individual plots, small fields, forests and other types of individual properties were still present.

Compared with the situation 100 year ago, the percentage of the land classed as agricultural is similar and only structural changes occurred in the 1950s. During this 100-year period, the area and number of commons decreased only slightly. More than $2 / 3$ of the former commons were preserved (Table 1) and they made up an important part of the landscape. Borders of the commons were usually clear and rarely violated. The biggest percentage of commons was lost to afforestation, which occurred at the beginning of the 19th century (Bičík 2010 in Vachuda 2017). About 5\% of former commons was converted into fields or meadows. Occasionally, some drainage or landscaping (e.g. removing big stones or levelling of the surface) were necessary. However, the extent of this landscaping was small compared with what happened in the coming decades. The area of agricultural land increased, but not very significantly. Some commons were built on and others abandoned and overgrown in the course of natural succession. Based on the aerial photographs, the preserved commons were those

Table 1 Percentage of preserved commons present at different times from 1850 s to 2019 .

\begin{tabular}{|l|r|r|r|r|}
\hline State of commons & $\mathbf{1 8 5 0 s}$ & $\begin{array}{c}\text { early } \\
\mathbf{1 9 5 0 s}\end{array}$ & $\begin{array}{c}\text { late } \\
\mathbf{1 9 9 0 s}\end{array}$ & $\mathbf{2 0 1 9}$ \\
\hline preserved & $100 \%$ & $76.5 \%$ & $30.2 \%$ & $12.1 \%$ \\
\hline built on & $0 \%$ & $2.5 \%$ & $6.0 \%$ & $6.3 \%$ \\
\hline converted to fields & $0 \%$ & $5.1 \%$ & $25.1 \%$ & $29.0 \%$ \\
\hline afforested & $0 \%$ & $8.1 \%$ & $12.1 \%$ & $12.7 \%$ \\
\hline abandoned & $0 \%$ & $3.7 \%$ & $22.3 \%$ & $34.7 \%$ \\
\hline other & $0 \%$ & $0.1 \%$ & $0.9 \%$ & $1.3 \%$ \\
\hline combination & $0 \%$ & $3.9 \%$ & $3.3 \%$ & $3.7 \%$ \\
\hline
\end{tabular}

that were not afforested, built on or abandoned and then subject to natural succession.

\section{The late 1990s}

The status of commons in the last years of the 20th century is the result of four decades of socialist agriculture and not always appropriate management of the Czech landscape. However, at the end of the 1990s, the effects of economic and property changes, which were implemented after the Velvet Revolution in 1989 (including privatization, abolition of agricultural cooperatives, reduction in arable land, etc.), are also evident. Until the 1990s, the agricultural policy in Czechoslovakia was influenced by farm nationalization and that resulted in significant changes in the landscape, predominantly in the percentage of arable land. In the early 1990s, landscape was affected by the change in ownership, both with restitution and privatisation. Especially agricultural land, which was divided among a large number of owners, but only a fraction of them farmed their land again (Kabrda and Bičík 2010). That led to abandonment, renting and changes in the use of these lands. When the restitution and restructuring was complete, comprehensive land adjustments began. In the aerial images, changes in the use of commons are very noticeable at this time.

The decrease in the number and acreage of commons continued. More than half of all commons disappeared and only one third were preserved (Table 1). The trend in transforming commons into agricultural fields escalated. In the late 1990s, a quarter of former commons were already converted into fields and being used as an agriculture field or a part of a large agricultural complex. Another $22.3 \%$ of commons was abandoned and left to natural succession. From the middle of the 20th century, there was a very rapid increase in population resulting in a $6 \%$ increase in built-up areas on unused parts of former commons. In addition, the percentage of afforested commons increased from $8.1 \%$ in 1950 s to $12.1 \%$ in the late 1990s (Table 1).

\section{The status of commons in 2019}

During the first 20 years of the new millennium there were still significant changes, which resulted in the transformation of former commons into other functional segments of landscape. The changes were not as significant as in the previous period. However, we must consider the length of the period, which was only two decades. The main driver of the transformation of commons in this period was the increase in the number of abandoned commons. In 2019, more than one third of commons had vanished due to natural succession. Abandoned, unmanaged commons became overgrown naturally because of a sequel of privatization in the 1990s and unclear ownership or speculation over the sale of the land. In addition, because in previous times the commons were often rocky or waterlogged localities with inaccessible terrain, it proved difficult to find an alternative use for them. 
Table 2 Changes in percentage of different land covers recorded in the different periods.

\begin{tabular}{|l|r|r|r|r|}
\hline Status of commons & $\mathbf{1 8 5 0 s}$ & $\begin{array}{c}\text { early } \\
\mathbf{1 9 5 0 s}\end{array}$ & $\begin{array}{c}\text { late } \\
\mathbf{1 9 9 0 s}\end{array}$ & $\mathbf{2 0 1 9}$ \\
\hline preserved & $100 \%$ & $-23.5 \%$ & $-46.3 \%$ & $-18.1 \%$ \\
\hline built up & $0 \%$ & $2.5 \%$ & $3.4 \%$ & $0.3 \%$ \\
\hline converted to fields & $0 \%$ & $5.1 \%$ & $20.1 \%$ & $3.9 \%$ \\
\hline afforested & $0 \%$ & $8.1 \%$ & $4.0 \%$ & $0.6 \%$ \\
\hline abandoned & $0 \%$ & $3.7 \%$ & $18.6 \%$ & $12.4 \%$ \\
\hline other & $0 \%$ & $0.1 \%$ & $0.7 \%$ & $0.4 \%$ \\
\hline combination & $0 \%$ & $3.9 \%$ & $-0.6 \%$ & $0.4 \%$ \\
\hline
\end{tabular}

Large agricultural complexes, commercial forests and urban areas were the most abundant structural elements in the landscape in 2019. The borders of former commons are not clearly visible and if so, mostly it is a border of an overgrown area, where natural succession has been occurring for a long time. Currently only about $12 \%$ of former commons remain (Table 1), but they have a high conservation value because they host a mosaic of vegetation.

\section{Almost two centuries of change}

There have been significant changes in the status of commons in the area studied since the middle of the 19th century. This period was divided into three, in which the changes are visible and can be easily evaluated. An illustrative series of pictures showing the transformation of commons over almost two centuries is in Appendix 1.

Decrease in the number and acreage of commons during these three periods was not uniform (Table 2). During the first period (1850s-1950s), the largest percentage of commons was lost due to afforestation. We assume that this was due to the beginning of the large afforestation at the end of the 19th century. In the following periods, this transformation was never that visible.

The biggest changes occurred during the second period (1950s-1990s), although this period was significantly shorter than the first. The main driver of change was amelioration, when almost a fifth of the commons was drained, big stones removed, ploughed and converted into agriculture fields and meadows (Table 2). Almost the same percentage was abandoned and left to natural succession.

In the last period, the above factors were of little significance except for abandonment (Table 2). Inappropriate management in previous times and ownership changes in the 1990s resulted in an increase in them being left to natural selection.

\section{Preserved commons}

Finally, analyses of maps together with the two-step field verification (autumn and spring) helped us to identify 49 preserved commons in the area studied. They were open with a mosaic of vegetation and their borders were well preserved and visible. Their distribution in the area of interest is very irregular and the predominant ecosystem in the cadastral area has no effect on the number of preserved commons (Fig. 5).

Our field surveys confirmed that many of the preserved commons consist of a mosaic of significantly valuable habitats, which are occupied by rare and protected species. The existence of a mosaic of habitats, mostly in extensively managed commons, in the current monotonous landscape is highly valuable from the conservation point of view. It is well established that these commons contribute to the conservation of species and habitat biodiversity. Their presence in the landscape is therefore crucial. The majority of the preserved commons are part of the Terrestrial system of ecological stability (Hrnčia-

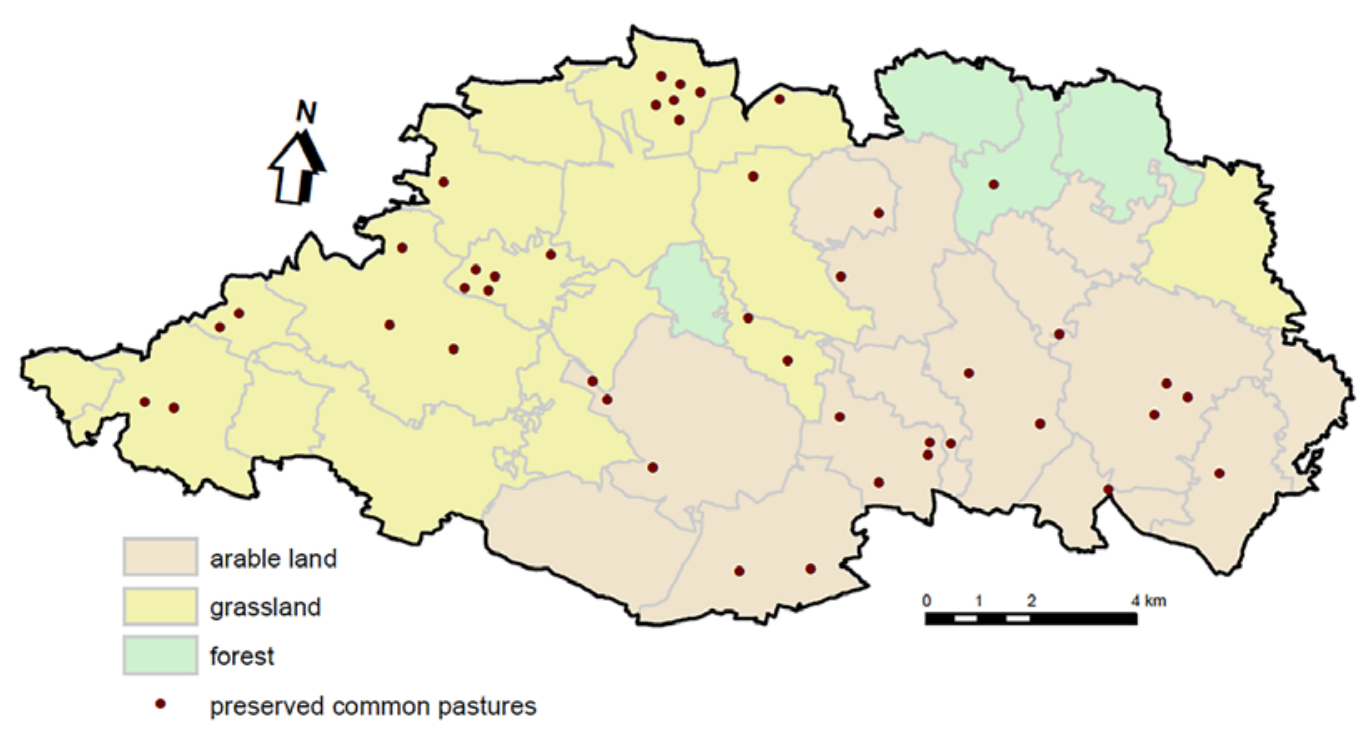

Fig. 5 Map showing the predominant ecosystem in each cadastral area and the distribution of preserved commons. 


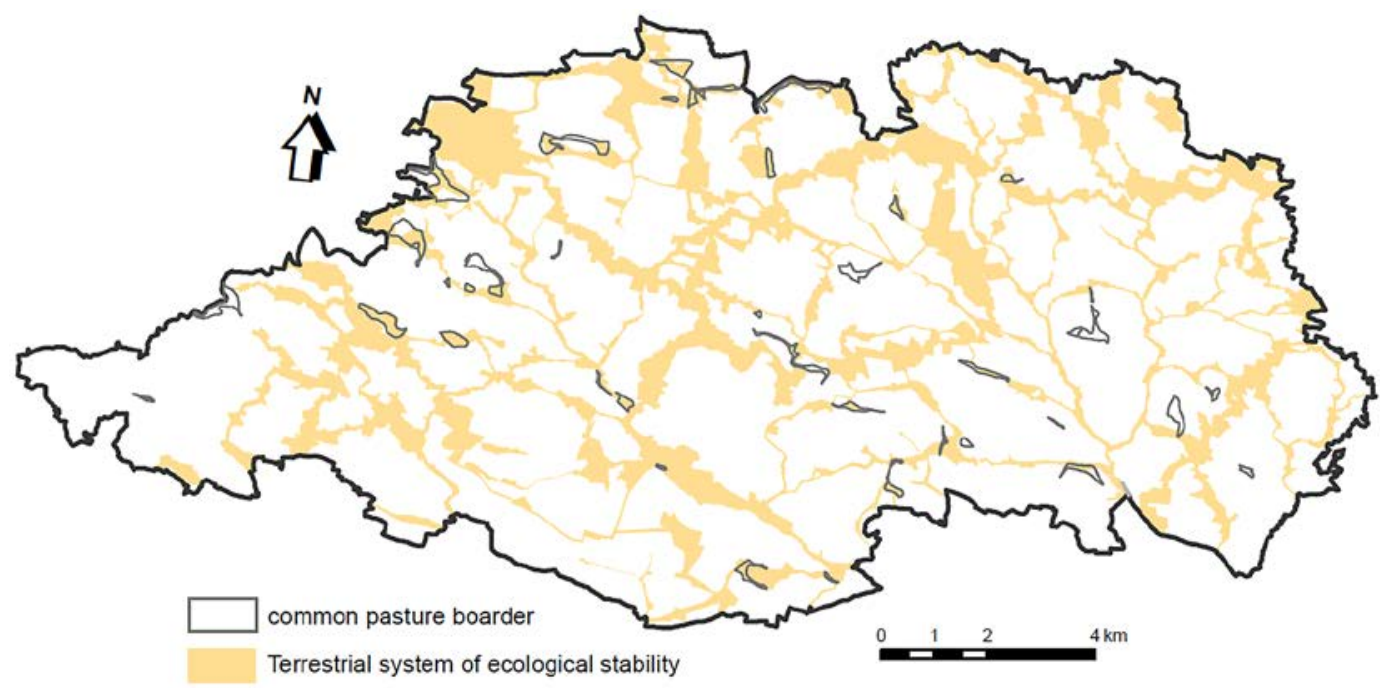

Fig. 6 Map showing the location of preserved commons and the Terrestrial system of landscape ecological stability.

rová et al. 2009; ecological networks in the sense of the Czech Nature Conservation Act No. 114/1992; Fig. 6). In total, $51 \%$ of the preserved commons mapped are local bio centres or local bio corridors.

\section{Discussion and Conclusions}

This study evaluated the current status of former commons, which were identified based on the maps of the Stable Cadastre, unique maps that cover the entire area of Bohemia, Moravia and Silesia (Semotánová 1998). Using these maps, it is possible to reconstruct the landscape present in the middle of the 19th century with a high degree of accuracy. They are an important source of knowledge on the character of the historic landscape and their accuracy enables one to digitally process and implement them in the geographic information system (GIS), which opens up further possibilities for analysing the structure of the historic landscape and comparing it with the current state (Brůna et al. 2004, 2006). Nedbal et al. (2008) and Brůna et al. (2010) state that the data from the Stable Cadastre are most suitable in terms of precision for monitoring the state and changes in the non-forest landscape. It was an essential basis for determining land taxes, and therefore both mapmakers and landowners were very interested in the exact details of the land and the determination of culture, i.e. the current use of land. The suitability of the maps of the Stable Cadastre for monitoring landscape changes in areas of increased conservation interest was also confirmed by this study, which focused on a selected type of land - commons.

In the area studied, which included 35 cadastral units, 668 former commons were identified. This area was selected because of the many well-preserved commons around Těchonice village, which is located in the mid- dle of the area studied. This rural countryside with poor infrastructure and many commons was a suitable study area. However, landscape structure in this area is similar to other Czech regions and the methodology used can be easily implemented in other similar areas. Worth noticing is that only a small number of commons larger than 1.5 hectares were recorded in this study. These commons can be grazed by large and, above all, more diversified herds, which results in a specific type of farming beneficial from the point of view of maintaining diversity. In addition, to the information on the size and frequency of commons in the land register, it was possible to determine whether and how the size of the land area and the size of the commons are related. We found only a slightly positive correlation, which was certainly influenced by the fact that individual cadastres not only differ in area, but also in other parameters (e.g. relief, soil stoniness, historical development, type of colonization, population densities).

The coverage of commons based on aerial images was determined for six basic categories, which were combined according to a predetermined procedure. In particular, the recognition of categories "abandoned" and "afforested" in some cases was unclear. Sometimes it was difficult to identify whether the current vegetation cover is the result of spontaneous overgrowth or tree plantings. The actual condition could not be verified in the field in all cases. However, a field survey of a selected subset of locations revealed only a few errors. The identification of the type of cover from the images from the 1950s and 1990s was carried out according to the same methodology as for the current images. Poor image quality often made it difficult to identify the cover accurately. However, an important criterion that often offset this inaccurate classification in historical pictures was the preservation of the boundaries of the commons. The boundaries of 
former commons were, in contrast to the current situation, mostly well distinguishable in images from the 1950s and 1990s.

The significant increase in all combinations of cover between 1950s-1990s and 1990s-2019 is not to be overlooked and was partly expected. This phenomenon is based on the general increasing tendency of land cover to change due to socio-economic changes occurring at that time.

An important period for significant changes in the use of commons was the collectivization of agriculture, which started in 1948. After this process, melioration occurred mainly in the 1960s-1970s. Many locations, valuable from the conservation point of view, however, were drained and converted to agriculture lands even during the second half of the 1980s. As reported by Luka et al. (2017) large-scale drainage significantly changed the Czech landscape.

Its main purpose was to expand the agricultural area and increase food production. The tendency towards food self-sufficiency thus caused the amelioration of a significant part of the landscape, whose functions had so far been other than just production. The commons could be an example of a part of the landscape, which have lost their mosaic and overall biological and cultural value. Commons used to be rich wetland localities, but due to amelioration, they were drained, ploughed and converted into fields. The same trend, i.e. converting of meadows and commons to arable land in the second half of the 20th century, is also mentioned by Kaninska et al. (2014), who examined changes in the landscape in the Slovak foothills. After the 1950s there was almost a 20\% increase in the number of abandoned commons. Many of them were abandoned already in 1920s or 1930s; however, successional changes were not too apparent during the first decades. Similarly, some commons recognized as abandoned during the socialist era (1950s-1990s) were in fact unmanaged already before or during WWII. They were not recognised as abandoned based on aerial photographs taken in the early 1950s because the successional changes were not recognizable at that time. Natural succession is usually slower and less apparent during the first years after the ending of management and overgrowth accelerates in the later stages of succession (e.g. Joyce 2014). In the area studied, this common trend was supported by social-economical changes during the communist era, when private and municipal ownership of the land completely disappeared and many chaotic measures escalating in succession could happen on abandoned commons (e.g. litter of old hay or manure, municipal waste landfills, irregular cutting of firewood etc.).

The high percentage of abandoned commons after 1990s can be explained by socio-economic changes during the last 30 years. Although these areas were returned to their original owners in the 1990s, not all subsequent owners had the tools, capacities, finances and will to restore the long-term abandoned former commons. Many of them continued to be uncultivated and succession continued. The speed of succession and the current amount of woody vegetation on these former commons was influenced by a number of factors, including both abandonment, previous management, local ecological conditions (soil, humidity, nutrient availability, etc.), diaspora source, various disturbances (game activities, casual visitors), change in techniques, etc. (Benjamin et al. 2005).

Answering the question raised by Hardin's essay (1968), we can say that the history of commons is not a complete tragedy, notwithstanding that our inventory revealed that three quarters of former commons have disappeared for different reasons. There is still, however, a great opportunity to save the rest of them and benefit from these treasures in our landscape. The existence of these extensively managed areas in our humdrum landscape is very important. This type of ecosystem provides many services. In contrast to intensive grazing, which forms the main part of the homogenized landscape, commons contribute to the preservation of species biodiversity, provide natural refuges for specific species and, among other functions, significantly help retaining water in the landscape. They significantly contribute to mitigating climate change and support sustainable landscape management. The cultural and historical significance for the local people and aspects of human well-being are also worth highlighting.

There are mosaics of significantly valuable habitats, in which populations of rare and protected species occur on all of the currently preserved commons. Some of them are managed for their conservation value: there is a nature reserve and several localities with endangered species, the management of which is paid from natural conservation funds. Local farmers or members of hunting clubs occasionally manage several others. However, many of the currently preserved commons lack appropriate management. More detailed evaluations of their conservation value and appropriate management are very much needed. More preserved and eventually restored commons should be included in the Territorial system of landscape ecological stability (i.e. ecological network), because they can play an important role as biodiversity stepping stones and improve the structure of the landscape.

\section{Acknowledgements}

We thank the following institutions and persons: A. F. G. Dixon for revising the language and J. Koreš for his endless and contagious enthusiasm for commons. This study was funded by the Ministry of Education, Youth and Sports of CR within the CzeCOS program, grant number LM2018123. 


\section{REFERENCES}

Benjamin K, Domon G, Bouchard A (2005) Vegetation composition and succession of abandoned farmland: effects of ecological, historical and spatial factors. Land Eco 20: 627-647.

Berg A, Ahrné K, Öckinger E, Svensson R, Söderström B (2011) Butterfly distribution and abundance is affected by variation in the Swedish forest-farmland landscape. Biol Conserv 144: 2819-2831.

Bičík I (ed) (2010) Změny využití ploch v Česku 1845-2000, Praha: Nakladatelství ČGS.

Brůna V, Křováková K (2006) Interpretation of stabile cadastre maps for landscape ecology purposes. International Conference on Cartography and GIS, Borovets, Bulgaria.

Brůna V, Křováková K, Nedbal V (2004) Analýza krajinných složek na mapách stabilního katastru. In.: Balej $\mathrm{M}$, Jeřábek M (eds) Geografický pohled na současné Česko. Acta Universitatis Purkynianae, Studia Geographica VI, UJEP, Ústí nad Labem.

Brůna V, Křováková K, Nedbal V (2010) Historical landscape structure in the spring area of Blanice river, Southern Bohemia - An example of the importace of old maps. Acta Geod Geophys Hu 45: 48-55.

Cenia (2017) Česká informační agentura životního prostředí. VÚKOZ - Klimatické oblasti(1901-2000) (accessed 21.4.2021).

Culek M, Grulich V, Laštůvka Z, Divišek J (2013) Biogeografické regiony České republiky. Masarykova univerzita, Brno.

ČÚZK (2020) Archivní mapy. Archiválie ÚAZK. Available from: https://archivnimapy.cuzk.cz/uazk/pohledy/archiv.html (accessed 21. 4. 2021).

Hardin G (1968) The tragedy of the commons. Science 162: 12431248.

Hodgson JA, Moilanen A, Wintle BA, Thomas, CD (2011) Habitat area, quality and connectivity: striking the balance for efficient conservation. J Appl Ecol 48: 148-152.

Hrnčiarová T, Mackovčin P, Zvara I et al. (2009) Atlas krajiny České republiky / Landscape Atlas of the Czech Republic.
Praha: Ministerstvo životního prostředí ČR, Průhonice: Výzkumný ústav Silva Taroucy pro krajinu a okrasné zahradnictví, v. v. i.

Joyce C (2014) Ecological consequences and restoration potential of abandoned wet grasslands. Ecol Eng 66: 91-102.

Kabrda J, Bičík I (2010) Dlouhodobé změny rozlohy lesa v Česku a ve světě. Geografické rozhledy 1/10: 11 .

Kaninska R, Kizeková M, Nováček J, Zeman M (2014) Land use and land-cover changes in rural areas during different political systems: A case study of Slovakia from 1782 to 2006. Land Use Policy 36: 554-566.

Luka V, Mertl J, Pernicová H, Ponocná T, Rejentová L, Rollerová M, Stein Z, Vlčková V (2017) Vývoj krajinného pokryvu dle CORINE Land Cover na území ČR v letech 1990-2012. Available from: http://www.nusl.cz/ntk/nusl-361852. (accessed 21. 4. 2021).

Mander Ü, Palang H, Ihse M (2004) Development of European landscapes. Land Urb Plan 67: 1-8.

Nedbal V, Křováková K, Brůna V (2008) Historická struktura krajiny a hospodaření v pramenné oblasti Blanice. Silva Gabreta 14: $199-220$.

Palang H, Printsmann A, Gyuró ÉK, Urbanc M, Skowronek E, Woloszyn W (2006) The forgotten rural landscapes of central and eastern Europe. Land Eco 20: 347-357.

Rook AJ, Tallowin JRB (2003) Grazing and pasture management for biodiversity benefit. Anim Res 52: 181-189.

Schwarz C, Trautner J, Fartmann T (2018) Common pastures are important refugees for a declining passerine bird in a pre-alpine agricultural landscape. J Ornithol 159: 945-954.

Semotánová E (1998) Historická geografie Českých zemí. Historický ústav AV ČR, Praha.

Vachuda J (2017) Analýza změn zemědělského land use v ČR a v modelovém regionu (katastrální území). [Analysis of land use changes in Czech Republic and local (cadastral) area. $\mathrm{PhD}$. Thesis, in Czech]. Faculty of science. Masaryk University. Department of Geography. Brno. Czech Republic. 


\section{Appendix 1}

A series of pictures showing changes over time in Malý Bor cadastre - an illustrative segment of the area studied. Red line - borders of common pastures.

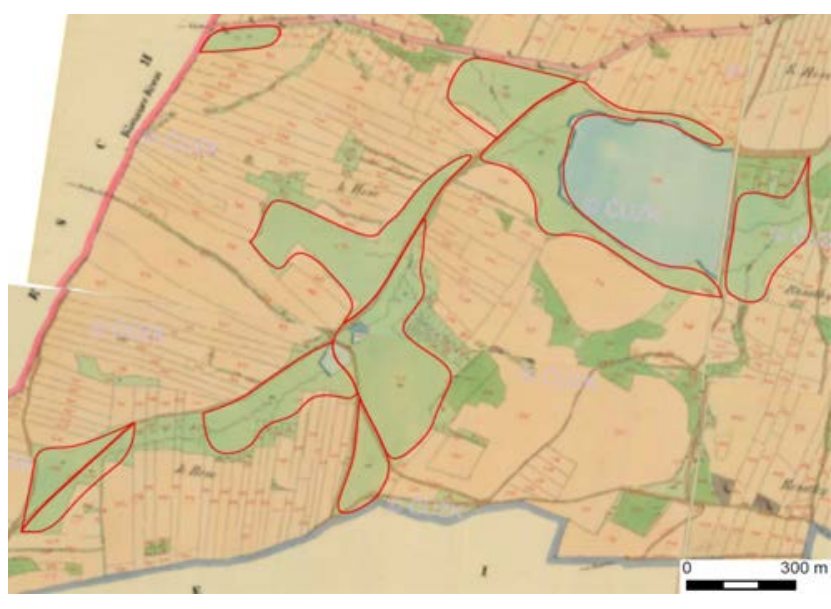

1850 s

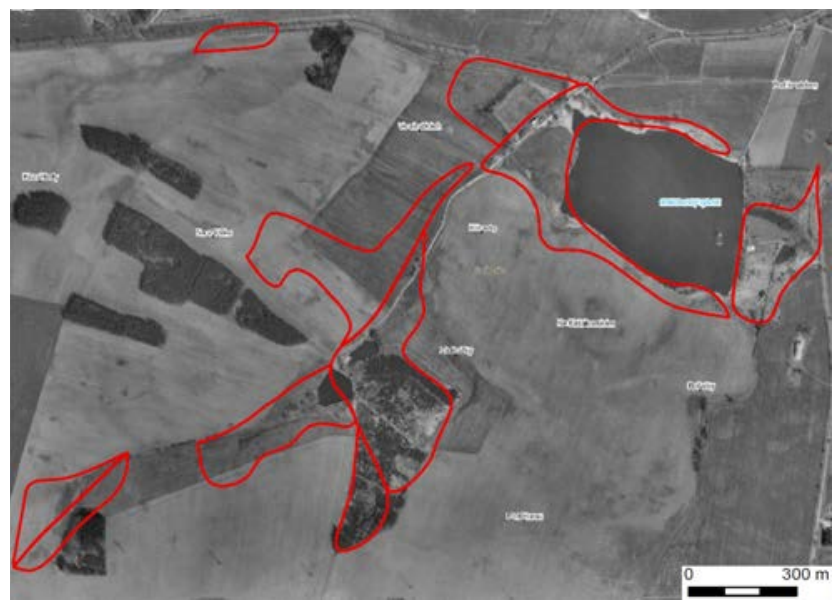

1990s

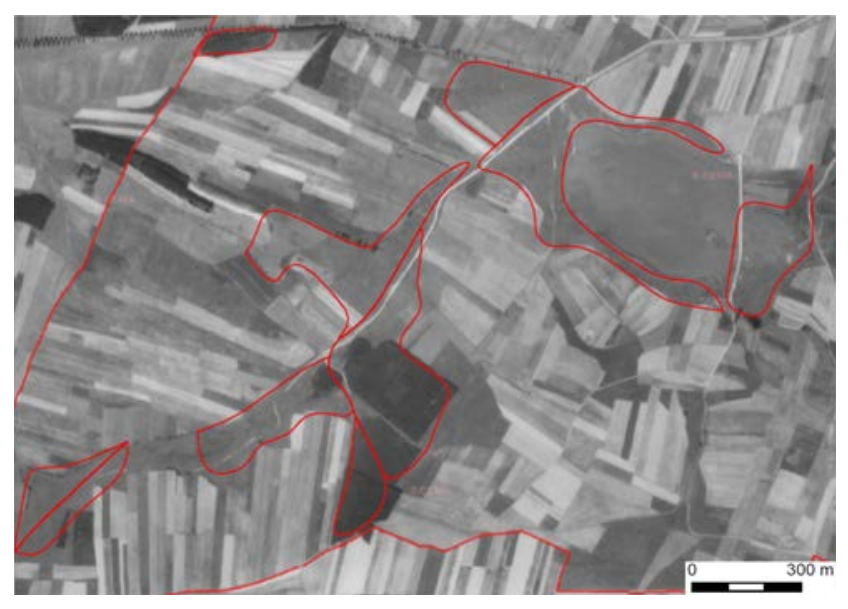

1950s

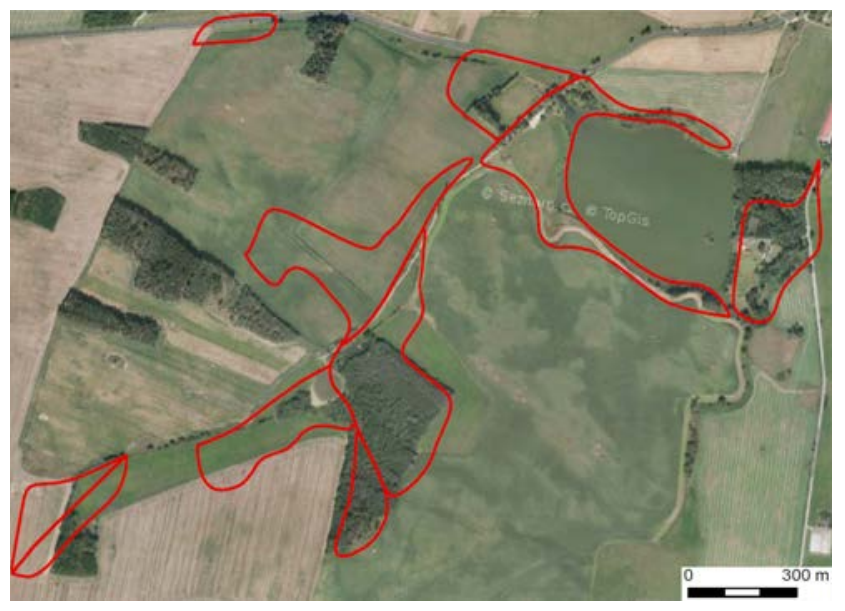

2019 